\title{
Curriculum Integration Model for Teaching Entreprenurial Skills at Senior Secondary School Level for Sustainable Employment Opportunities in Nigeria
}

\author{
Musa Mohammed Mande, \\ Department Of Educational Foundations, Faculty Of Technology Education, Abubakar Tafawa Balewa \\ University, Bauchi, Nigeria
}

\begin{abstract}
The implementation of the current educational system in Nigeria 6-3-3-4 as far back as 1980, was intended to device a new approach in providing an employment opportunities for the ever growing youth in Nigeria. The system in view, has all the needed characteristics to expose the senior secondary school learners with a life sustaining employment, unfortunately, for over three decades of the existence of this system (6-3-3-4) it has failed in achieving this noble objective. Greater population of secondary school leavers that could not continue with higher education due to lack of university requirement for admission or lack of the financial ability to sponsor their higher education, end up with a bleak future in our society today. Morover, the secondary school system could not provide the required training that can develop entrepreneurial skills to these children due to lack of teaching equipment, workshops in our schools. It is in recognition of these problem, this paper tries to integrate skills acquisition process that will provide the necessary entrepreneurial skills for sustainable employment opportunities in Nigeria.
\end{abstract}

\section{Introduction}

Shane and Venkataraman (2000) defined entrepreneurship as the study of how, by whom and with what effects opportunity to create future goods and services are discovered, evaluated and exploited. Shane and Venkataraman had a correct and impressive view of the concept entrepreneurship. In any case of business enterprise, it is always pertinent to understand how such enterprise should be established and also who is in a good position to establish it. These provide the information on how it will make an impact to the society as a whole. Shane and Venkataraman (2000) further looked at entrepreneurial opportunities as those situations in which new goods, services, raw materials and organizing methods can be introduced and sold at greater than their costs of production. Therefore, any goods, services or raw materials that an individual acquires and can sell such and realize a profit is rightly considered as an entrepreneurial activities according to the submission of Shane and Venkataraman.

Okpara (2005) defined entrepreneurship as the willingness and ability of an individual to seek out investment opportunities, establish and run an enterprise successfully. The idea of Okpara has a limitless boundary to the concept entrepreneurship, this means, any opportunity an individual can exploit that will help him establish and run an enterprise is considered as an entrepreneurship.

Okpara (2005) further identified entrepreneurial qualities as innovation, autonomy, creativity, determination, flexibility, good orientation, hard work, imagination, initiating, others are, leadership, need for achievement, optimism, perseverance, persuasive powers, problem-solving ability, futuristic, confidence and individuality. The inpending difficulties and risks in entrepreneurial activities, are the brain behind advising an entrepreneur to process the above qualities, this will provide him the mental readiness to face the challenges and have the zeal to succeed in his enterprise.

Okpara (2005) identified characteristics of an entrepreneur as self-confidence, task or result oriented, risk taker, leadership, originality and future-oriented. Indeed, one can hardly succeed in entrepreneurial activities without one possessing the above characteristics outlined by Okpara. These will give him the expected focus on whatever he wants to achieve in his enterprise. In the sense that, the entrepreneur is considered as action oriented highly motivated individual who takes risk to achieve goal.

Calvin, (2006) being an entrepreneur or small business manager satisfies our personal needs for freedom, flexibility, variety, creativity, responsibility, control and authority. In order for an individual to succeed in entrepreneurial activities, has to endeavour to possess these potentials. These stabilize him in the venture, which will bring the expected reward or profit.

According to Jesscia, Trayce and Kristen (2014). Three integrated curriculum models have proven successful with gifted and talented students. These include:

An overarching concept reading, reflections and discussion provide students with opportunities to create and construct meanings for key concepts. This allows for cross curricular connections. (2) Advanced 
content-pre-assessments allow students the opportunity to show mastery of concepts and skills in content areas. Teachers are also able to compact the curriculum and guide students through advanced content at a more rapid pace. (3) Process/product-self-directed learning allows students to explore a topic of personal interest. They construct knowledge and apply it to product that are highly qualitative.

The above submission, has shown that, curriculum integration model if properly applied can positively change an educational practice. There are so many educational literature that support curriculum integration, cognitive scientists were able to utilize advanced imaging technologies to study how the brain operates. Jenson (1998) the single best way to grow a better brain is through challenging problem solving, this creates new dendritic connections that allows us to make even more connections. This means, whenever a human brain is challenge with a reasonable and meaningful cognitive activity, will motivate a sound connection between learning concepts.

Wolf \& Brand, (1998). One of the best ways to promote problem solving is through an enriched environment that makes connections among several disciplines. It is an acceptable fact that, learners cannot develop the potentials for problem solving ability in an environment which is not conducive. Hence, learners should be exposed to an environment that has the characteristics needed for learners to establish connections among several disciplines.

Austin, Hirstein \& Walen, (1997) Educational researchers have found that an integrated curriculum can result in greater intellectual curiosity, improved attitude towards schooling, enhanced problem-solving skills and higher achievement in college. This is usually the essence of educational exposure, to develop the ability of problem-solving. If learners develop this ability than education has become a viable venture.

Barad and Linda, (1997) indicated that when students focus on problems worth solving, motivation and learning increase. The idea presented by Barad and Linda has added yet another opinion that encourages problem-solving capacity in a learner.

Kain (1993) some schools have used an integrated curriculum as a way to make education relevant and thus a way to keep students interested in school. It is an acceptable fact that, integrated curriculum usually is activity-based problem. Naturally learners are more interested in an activity oriented learning conditions where they participate as active members not a passive situation that usually brings so much boredom to the learning activity.

\section{Improved Curriculum Integration Model}

\section{Table 5: Mohammed's improved model of curriculum integration}

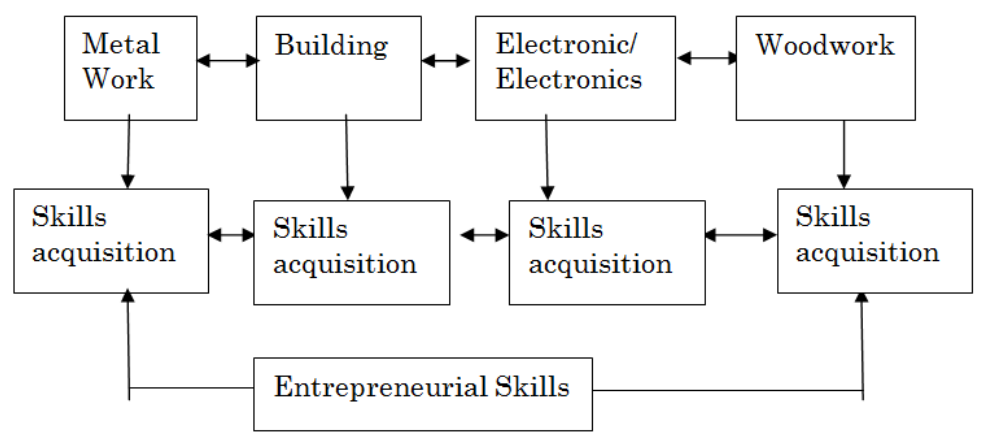

The model attempts to establish some of the related Basic technology subjects identified under the programme. These skills cannot be easily acquired in the classroom and secondly, the schools do not have the required equipment for teaching these subjects in basic technology skills. Therefore, the programme has to incorporate practical skills. The skills will be acquired though attaching the learners to various technicians in the community where they will have a practical exposure. This approach will guarantee the child to develop the expected entrepreneurial skills inherent in basic technology.

\section{Entrepreneurial Skills opportunities in Senior Secondary School Curriculum}

Federal Ministry of Education (2007) had sponsored the production of senior secondary education curriculum in plumbing and pipe fitting, basic electronics, Auto mechanics, Auto Body repair and spray painting and refrigeration and air conditioning etc the primary objective is to provide entrepreneurial skills to the senior secondary school products. It is a viable venture if and only if the federal and states governments have the zeal and political will to provide the required equipment, materials and workshops for teaching these subjects areas.

\section{Plumbing and pipe fitting: -}

Federal Ministry of Education (2007) This subject area has topic like safety rules and regulations on the site, hand tools maintenance, equipment and maintenance, surface water, under ground water, water 
treatment method, types of pipes, pipe fitting, pipe jointing. Others are reservoirs, piping system, sewage, well water, borehole sedimentation, sand filtration, chlorination, plumbing, sanitary appliances, sanitary fittings symbols and conventions pipe fitting materials, methods of laying pipes drainage system.

\section{Refrigeration and Air Conditioning: -}

Federal Ministry of Education (2007) This is a subject area that deals with topics like safety in the workshop, first aid, energy, nature of matter, temperature and its measurement, pressure and its measurement, introduction to refrigeration, refrigerants, conditioning system, servicing an air conditioner. Others are, refrigerant flow controls, piping, ducting and trucking insulation of air condition and refrigeration systems, fault diagnosis and trouble shooting, liquid receiver and service value, motors and generators cold room, maintenance and testing.

\section{Auto Body Repair and Spray Painting: -}

Federal Ministry of Education (2007) The area deals with concepts like general rules and regulations in auto-body repair workshop, sources of accident, prevention and accident, identification of tools and equipment for auto body repair and their uses, care and maintenance of tools and equipment, auto body work materials, type of metals, heat treatment of materials, types of auto body repair work, oxyacetylene welding equipment, safety precautions to be taken in auto body paint shop, materials and equipment for auto body repair and spray painting. Others are, paint materials, care and maintenance of tools and equipment minor auto body repair, major auto body repair, spray gum and accessories, surface preparation, machines, maintenance of machine.

\section{Auto Mechanics: -}

Federal Ministry of Education (2007) The major subject area coverage include vehicle layout, auto workshop, safety in auto mobile workshop, engine types, engine components, principles of four stroke circle (petrol and diesel), principles of two stroke cycle (petrol and diesel), system layout, clutch assembly, gear box, propeller shaft and universal joint, rear axle assembly, auto wiring system, ignition system, starting system, preventive maintenance. Others are, fault diagnosis, lighting system, cooling system and its requirements, air and water cooling system, crank arrangement, fuel, exhaust system, tiring order, road wheels and tyres, brake system, lighting system and ignition system.

\section{Basic Electronics: -}

Federal Ministry of Education (2007) This is an area that deals with concepts like, electrical current, relationship between voltage, current and resistance, electric power, circuit components, electric current, magnet and magnetic field, electromagnetism, electron emission, semi conductor, semi conductor diodes, alternating current circuit, power in AC circuit, Transistors, Integrated circuits (IC) and microprocessors, others are, power supply system, radio transmission and reception, television receiver, hand tools, measuring instruments, transducers and sensors, acoustic transducers, number system, logic gates, amplifiers, feedback circuits, satellite and control circuits.

\section{Instructional Materials And Equipment For Teaching}

Federal Ministry of Education (2007) In order to effectively give the senior secondary school student sound instructional process in these subject areas, there is the need to provide the needed instructional materials, workshops and equipment. These include:

Materials and equipment for teaching plumbing and pipe fitting including, charts, posters, video and software materials on safety, hand tools, manufacturer's manual on hand tools, equipment soft wares, water containers, water samples, jointing materials alum (coagulant) or iron compound, perforated water containers, sand, water and gravel, others include, welding tools and equipment, dizing machine, laying tools sketches, carrying out pipe laying task, plumbing plans, junctions and pieces of pipes, various pipe fittings, drainage pipes and fittings.

Federal Ministry of Education (2007) The instructional materials are equipment for teaching refrigeration and our conditioning include: pictures and charts, safety devices and equipment like fire extinguishers, safety bucket, soft ware on workshop rules and regulations, computer system, different forms of matter eg solid, liquid and vapour, different types of thermometers, measuring devices like barometer, manometer, bourdon, tube gauge, cylinders of different types of refrigeration, different types of compressors, different types of evaporators, spring benders, reamers, tools for servicing air-conditioners, window unit airconditioner, others include, suctions and pressure gauges, psychometric chart, different types of flow controls, tools and materials for servicing flow controls, copper pipe, aluminum pipe, capillary tube, oxy-acetylene gas, flux, welding torch, welding shield easy flow, service tools and equipment, condenser and evaporation pipe, split unit air conditioner, tools flaring, cutter, silver tape, am flex, pvc pipe, glass, rock, slag, wood, refrigerator, 
ceramic, refrigeration and air-condition accessories e.g relays, capacitors, valve, thermostat, repair kit, service kit, set of spanner motors and cold room service kit.

Federal Ministry of Education (2007) The instructional materials and equipment for teaching auto body repair and spray painting include, charts, fire extinguishers, hand gloves, overall, safety boots, nose mask goggles, real objects like tools, machines, and oil. Others are, hammers, dollies, spanners, drilling machine, air compressor, car body, body fillers, abrasives, cast iron, aluminum copper, chisels, welding equipment, thermometer, oxygen cylinder, acetylene cylinder, safety chain, blow pipe, nozzles, spray gum, thinner primer, primer surface, enamel paint, lacquers, top coat, sealer, manufactures basic colour guide, thinner brush, thermosetting and thermoplastic.

Federal Ministry of Education (2007) Auto mechanics requires the following teaching materials and equipment: Real objects, chalkboard, chart, projector, demonstration, petrol, diesel, engine analyzer, timing light, vacuum pump, scanners, computer, alignment equipment, engine valve, lead-acid battery, auto workshop, car body, different vehicle engines, old compressors, old car clutch, gear box, propeller shaft, real axle, old car ignition, crank shaft, car gear box.

Federal Ministry of Education, (2007), The instructional materials and equipment recommended for this subject area include, charts showing structure of an atom, copper wire, pieces of wood, dry cell battery, calculators, circuit boards, ammeter, ohmmeter, voltmeter, resistors, capacitors, inductors, bar magnets, iron filing zip drive, magnetic tape, floppy disk, electromagnet solenoid, transformer, electric bell, relay, thermionic valve, semi conductor diodes, micro processors, charts on radio transmission system, radio receiver, multimeters oscilloscope. Others are, hand tools, measuring instrument both analogue and digital, loudspeakers, microphones, amplifier circuit, GSM phones, web connector.

\subsection{The need for integrating skill Acquisition into senior secondary school curriculum}

Education in Nigeria has suffered a total neglect over the years, the stakeholders in education are always giving lips service to the sector, with ever increasing budgetary allocation to it but at last nothing is seen towards improving the sector. Taking a closer look at the technology related curriculum for senior secondary school, one can conclude that, if such a curriculum is implemented to the core, one can predict a brighter future for our children. The unfortunate condition of education in Nigeria today, is the general lack of professional teachers, equipment, workshops and instructional materials.

Therefore, the secondary school products will ultimately graduate without the required skills. It is for the above reason, this paper is proposing a skill acquisition process for the senior secondary school students in order to give them the required educational treatment in the above mentioned entrepreneurial opportunities.

Learning plumbing and pipe fitting, the secondary school curriculum should use the services of our local plumbers and pipe fitting experts to train the students. Obviously, the government can hardly supply all the needed instructional materials in teaching this subject area. Secondly, it is an area that teaching should go beyond classroom interaction, practical exposure will provide a better technical proficiency to our student not the usual theoretical instruction that characterized our educational system.

Our local communities are blessed with so many experts in maintenance and installation of refrigerators and air conditioners. The educational system can use the services of these experts in teaching the subject area related to refrigeration and air conditioning. The secondary schools in Nigeria are ill equipped with the instructional materials, equipment and workshops for teaching the area. Employing the services of these local technicians solves the problems of lack of teachers in the area and shortage or non-availability of the teaching materials.

The panel beaters that usually do the work of auto body repair and spray painting can be a good source of teachers and teaching materials in this subject area. It is important to understand that most if not all, technical teachers we have today and not undergo the required training in this area; even of they do, not all will sustain the physical agility to teach our students the area, for the simple fact that, it requires a lot of strength. Therefore, utilizing the local craft men and technicians in this area will go a long way in solving the problem and giving the students the required skills they need to have sufficient entrepreneurial abilities.

Auto mechanic is yet another area that the educational system cannot sustain. The materials for teaching this area are capital intensive, going by the traditional lukewarm attitude of our stakeholders in education; the materials cannot be purchased for the instructional purposes. Hence, this calls for the engagement of technicians and mechanics to handle the area.

Basic electronics too, is subject with so many demands in terms of teaching equipment. In order to curve the problem of lack of these materials in our secondary schools, the local mechanics in electronics ranging from radio to television through satellite can be employed to handle the area. 


\section{Conclusion}

The essence of evolving these curriculums for the senior secondary school students is to curve the problem of unemployment in Nigeria. It has been observed that youth that graduate from secondary schools that usually fall within the ages of 18-19, do not have a means of livelihood; especially if they did not proceed to tertiary institutions due to deficiency of entry qualification. Therefore, their existence in our streets is a great security challenge to the Nigerian nation. Hence, the need to have a curriculum solution to this problem. The development of curriculum that will provide entrepreneurial abilities to their children will obviously improve the situation. However, this will not be possible if the skills mentioned or enshrined in these curriculum is not properly taught to the students. Therefore, the integration of this model of curriculum integration hopes to give the product the entrepreneurial skills by using our local technicians, mechanics and specialists in different technical areas.

\section{Recommendations}

The following recommendations are advanced for better integration endeavour.

(1) The technicians should be employed by the state and federal government to teach their respective schools.

(2) The instructional process should take place in their workshops of these mechanics and technicians.

(3) It should be in a form of attachment to these technicians and mechanics using Saturdays and Sundays for their instruction.

(4) The contact or attachment should begin from SS I to SS III, that is in a period of three years.

(5) The government should give those not proceeding to tertiary institution a working capital or stand as a guarantor in seeking bank loans.

(6) The local artisans and technicians that will be employed for the instructional purposes of the programme should be given a reasonable salary package.

\section{References}

[1]. Austin, J.D, Hirstein, J., and Wajen, S. (1997). Integrated Mathematic interfaced with sciences. School Science Mathematics 97 (1), 45-49.

[2]. Barab, S.A, and Landa, A. (1997). Designing effective interdisciplinary anchors. Educational leadership, 54 (6), $52-58$.

[3]. Calvin, R.J. (2006). Entrepreneurial Management India. Tata McGraw-Hill Publishing Company Ltd.

[4]. Federal Ministry of Education (2007). National policy on education NERDC press, Lagos.

[5]. Federal Ministry of Education, (2007). Senior Secondary School Curriculum; Auto Mechanics, Abuja, Nigerian Educational Research and Development Council.

[6]. Federal Ministry of Education, (2007). Senior Secondary School Curriculum; Basic Electronics, Abuja, Nigerian Educational Research and Development Council.

[7]. Federal Ministry of Education, (2007). Senior Secondary School Curriculum; Plumbing and Pipe Fitting, Abuja, Nigerian Educational Research and Development Council.

[8]. Federal Ministry of Education, (2007). Senior Secondary School Curriculum; Refrigeration and Air-conditioning, Abuja, Nigerian Educational Research and Development Council.

[9]. Federal Ministry of Education, (2007). Senior Secondary School Curriculum; Auto Body Repair and Spray Painting, Abuja, Nigerian Educational Research and Development Council.

[10]. Jensen, E. (1998). Teaching with the brain mind. Alexandria, VA: Association for supervision and curriculum Development.

[11]. Jesscia, R. Trayce, W, and Kristen, H. (2014). Integrated curriculum model. Retrieved from http://www.freetdb.com/detail integrated-curriculum-model-105981. htm on 15 July, 2014

[12]. Kain, D.L. (1993). Cabbages and Kings: Research directions in Integrated/ Interdisciplinary curriculum. The Journal of educational thought, 27(3), 312-331.

[13]. Loepp, P. (2004). Retrieved from http:// scholars, Lib.Vt.edu/ejournals/JOTS/summer- fall-1999/PDF on $19^{\text {th }}$ June, 2014

[14]. Okpala, O.O. (2005). The practice of entrepreneurship. Precision publish Limited, 2005.

[15]. Shane and Venkataraman (2000). Entrepreneurial Management, Tata McGraw Hill Publishing Company Ltd. New York.

[16]. Wolf, P. and Brand, R. (1998). What do we know from brain research? Educational leadership, 56 (3), 8-13. 